\title{
Evidence of unmet need in the care of severely physically disabled adults
}

\author{
M H Williams, C Bowie
}

\begin{abstract}
Objective-To identify unmet needs in the care of severely disabled people aged 16-64.

Design-Detailed personal interview and physical assessment of physically disabled adults; personal or telephone interview with carers.

Setting-Somerset Health District.

Subjects-181 severely disabled adults and their carers.
\end{abstract}

Main outcome measures-Independence in activities of daily living; identity of requirements for assessing communication disorders; appropriate provision of services and allowances.

Results-53 $(29.3 \%)$ of the 181 disabled subjects had unmet needs for aids to allow independence in activities of daily living-namely, $43 \%$ of subjects (41/95) with progressive disorders and $14 \%$ of subjects (12/86) with non-progressive disorders. The prevalence of unmet need was higher among subjects whose sole regular professional contact was with health services personnel $(48(40 \cdot 3 \%)$ of 119 subjects). Only $18(31.6 \%)$ of the 57 subjects with communication disorders had ever been assessed by a speech therapist.

Conclusions-This study shows that the needs of severely physically disabled adults in the community -especially those with progressive disorders-are being monitored inadequately by health professionals.

\section{Introduction}

The white paper Caring for People ${ }^{1}$ and the NHS and Community Care Act $1990^{2}$ set out the government's policy framework for community care in the next decade. A principal objective is to enable people to live an independent and dignified life in the community for as long as they are able and wish to do so. The importance of effective assessment in ensuring high quality care of physically disabled people is emphasised, as the capacity to maintain independence may be influenced by the subsequent provision of aids, services, etc.

This study, planned jointly by Somerset Health Authority and Somerset social services department and carried out during 1989-90, focused on the quality of monitoring and management of the needs of a sample of severely physically disabled residents of Somerset Health District who were in regular contact with health professionals.

$B M \mathcal{F} 1993 ; 306: 95-8$

TABLE I-Definition of groups of young physically disabled people for analysis

\begin{tabular}{|c|c|c|c|c|}
\hline Group & $\begin{array}{l}\text { No of } \\
\text { subjects }\end{array}$ & $\begin{array}{c}\text { Mean age } \\
\text { (years) } \\
\text { (range) }\end{array}$ & $\begin{array}{c}\text { Mean } \\
\text { severity } \\
\text { category }\end{array}$ & Services in contact with patient in 12 months before interview \\
\hline A & 12 & $29(16-58)$ & $9 \cdot 8$ & General practitioner only (four or more consultations per annum) \\
\hline B & 10 & $44(20-54)$ & $9 \cdot 9$ & $\begin{array}{l}\text { Group A services plus hospital outpatient appointment (twice or more } \\
\text { per annum) with or without hospital admission }\end{array}$ \\
\hline C & 46 & $42(16-52)$ & $9 \cdot 9$ & Group B services plus district nurse visit (once or more per week) \\
\hline D & 51 & $42(20-64)$ & $9 \cdot 9$ & $\begin{array}{l}\text { Group C services plus social worker or occupational therapist } \\
\text { assessment on request by patient or carer, or both }\end{array}$ \\
\hline $\mathrm{E}$ & 42 & $39(16-58)$ & 9.9 & $\begin{array}{l}\text { Group } \mathrm{C} \text { services plus social worker or occupational therapist } \\
\text { assessment two or three times per annum regularly }\end{array}$ \\
\hline $\mathrm{F}$ & 20 & $48(20-63)$ & $9 \cdot 8$ & Group E services plus voluntary agency contact \\
\hline
\end{tabular}

*As defined by Office of Population Censuses and Surveys. ${ }^{+}$

\section{Subjects and methods}

A total of 557 severely physically disabled adults aged 16-64 were initially identified from available records and consultation with health professionals, social workers, and voluntary services. Included were adults whose primary disabilities were physical and permanent and who needed daily assistance from carers or other professionals or non-professional helpers. This definition has been used in other studies. ${ }^{3}$ Excluded were residents of institutions, mentally handicapped people, and those whose primary disability was deafness or blindness.

A $33 \%$ random sample of subjects $(n=184)$ was selected for intensive study, of whom $181(98 \%)$ agreed to participate. Each person was interviewed at home by a doctor trained in physical disability. Of the principal carers, $177(98 \%)$ were interviewed in person and four by telephone. Information about the subject's disabilities and handicaps and the current provision of health and social care, voluntary services, and allowances (subsequently validated against available records) was recorded on a standard questionnaire. Physical examination ascertained independence in six activities of daily living: feeding; dressing; transfer from chair, bed, or toilet; bathing; toileting; and locomotion. By applying a formula to the three highest scores from 13 areas of disability, as defined by the Office of Population Censuses and Surveys, ${ }^{4} 161(89 \%)$ subjects were placed in category 10 , and $20(11 \%)$ subjects in category 9, the two highest bands of severity. The 119 people who were wheelchairbound had their wheelchairs assessed for defects. In all cases where unmet needs were identified referral was made to the appropriate agency or professional after agreement with the client's general practitioner.

Need has been variously defined, ${ }^{5-8}$ but in this study needs were deemed to be unmet if interventions were acceptable to the client and the following applied: (a) for activities of daily living a person was dependent on help from the carer and this dependence could be reversed by provision of an aid; (b) for communication disorders there had not been an assessment by a speech therapist; $(c)$ for services (day care, respite care) a referral had not been made to the appropriate agency and subsequent referral proved successful; and $(d)$ for benefits the client or carer was unaware of eligibility for benefits, an application had not been made, and subsequent application was successful.

\section{Results}

CONTACT WITH SERVICES IN PREVIOUS 12 MONTHS

Using information on the health, social, and voluntary services in regular contact with the 181 physically disabled people in the 12 months before interview, we subdivided the sample into six groups (A-F). The definitions for inclusion in these subgroups and the underlying diagnoses are summarised in tables $I$ and II. Members of the sample had consulted their general practitioners a mean of $7 \cdot 0$ times (range $4-15$ ). A total of $169(93 \%)$ had received at least two hospital outpatient consultations in connection with the condition causing their disability, of whom 25 (15\%) had also required inpatient admission. One hundred and 
fifty nine subjects $(88 \%)$ were visited one to three times per week by the district nursing service. Sixty eight $(38 \%)$ had not had contact with social or voluntary services in the previous three years; $51(28 \%)$ had been advised to contact social services "if the need arose"; and only $62(34 \%)$ people had received regular visits from social services personnel (social workers, occupational therapists, etc).

\section{ACTIVITIES OF DAILY LIVING}

Table III summarises the numbers in each subgroup initially dependent on the carer but subsequently independent with respect to activities of daily living after provision of aids. Overall, 53 subjects (29.3\%) achieved independence in at least one activity: 36 $(19.9 \%)$ achieved independence in three activities, $12(6.6 \%)$ in two, and five $(2.8 \%)$ in one. Of the 119 subjects who were wheelchairbound, $12(10 \cdot 1 \%)$ had remediable defects in their wheelchairs.

Progressive versus non-progressive disorders-The diagnostic groups were broadly classified into progressive and non-progressive disorders (table II), stroke patients being placed in the second group for analysis. The highest prevalences of unmet need were consistently found in groups A to D (table IV). Overall, 41 $(43 \%)$ of the 95 subjects with progressive disorders benefited from aids compared with $12(14 \%)$ of the 86 with non-progressive disorders $(p<0.001)$.
Hospital inpatients versus hospital outpatientsAmong subjects with progressive disorders receiving hospital consultations (table IV), none who had been admitted as an inpatient in the past 12 months had unmet needs. By contrast, almost half of subjects who had received solely outpatient consultations had unmet needs $(p<0.001)$. There was little difference in the respective proportions of subjects with non-progressive disorders $(10 \% v 9 \%$; NS) (table IV).

Contact with health professionals-Among subjects with progressive and non-progressive disorders the proportions with unmet needs were significantly higher ( $p<0.01$ and $p<0.001$ respectively) in groups A to $\mathrm{D}$, where regular contact was solely with health professionals, than in groups $\mathrm{E}$ and $\mathrm{F}$, where there was also regular input from the social and voluntary services (table IV).

\section{COMMUNICATION DISORDERS}

In groups $A$ to $E$ inclusive 57 patients with communication disorders were placed in three grades of disability. Only 18 patients, including only half of the most severely affected group, whose speech carers found impossible to understand, had ever received an assessment by a speech therapist (table V). In addition, five patients with motor neurone disease suffered from swallowing disorders, of whom only two had been assessed.

TABLE II-Diagnostic groups within subgroups $A-F$

\begin{tabular}{|c|c|c|c|c|c|c|c|c|c|c|c|c|}
\hline \multirow[b]{2}{*}{ Group } & \multicolumn{5}{|c|}{ Progressive disorders } & \multicolumn{6}{|c|}{ Non-progressive disorders } & \multirow[b]{2}{*}{ Total } \\
\hline & $\begin{array}{l}\text { Rheumatoid } \\
\text { arthritis }\end{array}$ & $\begin{array}{l}\text { Multiple } \\
\text { sclerosis }\end{array}$ & $\begin{array}{c}\text { Motor } \\
\text { neurone } \\
\text { disease }\end{array}$ & $\begin{array}{l}\text { Muscular } \\
\text { dystrophy }\end{array}$ & $\begin{array}{l}\text { Chorea/ } \\
\text { ataxia }\end{array}$ & Stroke & Congenital & Paraplegia & Tetraplegia & $\begin{array}{l}\text { Head } \\
\text { injury }\end{array}$ & Other ${ }^{\star}$ & \\
\hline $\begin{array}{l}\text { A } \\
\text { B }\end{array}$ & 6 & & & 3 & & 1 & 6 & 2 & & & & $\begin{array}{l}12 \\
10\end{array}$ \\
\hline C & 16 & 5 & 3 & 7 & 3 & 4 & 3 & 3 & & 2 & 4 & $\begin{array}{l}10 \\
46\end{array}$ \\
\hline D & 5 & 8 & 5 & & 4 & 4 & 9 & 4 & & 9 & 3 & 51 \\
\hline $\mathrm{E}$ & 9 & 9 & & & & & & 7 & 13 & 4 & & 42 \\
\hline $\mathrm{F}$ & & 12 & & & & & & 4 & 4 & & & 20 \\
\hline Total & 36 & 34 & 8 & 10 & 7 & 9 & 18 & 20 & 17 & 15 & 7 & 181 \\
\hline
\end{tabular}

«"Other" refers to four patients with two or more limb amputations and three with disability as a result of poliomyelitis.

TABLE II-Unmet needs for aids to assist activities for daily living

\begin{tabular}{|c|c|c|c|c|c|c|c|c|c|}
\hline \multirow[b]{2}{*}{ Group } & \multirow[b]{2}{*}{ Diagnosis } & \multirow{2}{*}{$\begin{array}{l}\text { No of } \\
\text { subjects with } \\
\text { unmet needs }\end{array}$} & \multicolumn{6}{|c|}{ Aids required for independent activity } & \multirow[b]{2}{*}{$\begin{array}{l}\text { Wheelchair } \\
\text { fault }\end{array}$} \\
\hline & & & Feeding & Dressing & Transfer & Toilet & Bath & Ambulation & \\
\hline \multirow[t]{4}{*}{ A } & Muscular dystrophy & 3 & 1 & 1 & 3 & 3 & 3 & & \\
\hline & Stroke & 1 & 1 & 1 & 1 & & & 1 & \\
\hline & Paraplegia & 2 & & & 2 & & 2 & & 2 \\
\hline & Congenital disorder & 2 & & & 1 & 2 & 1 & 1 & \\
\hline \multicolumn{2}{|l|}{ Total } & 8 & 2 & 2 & 7 & 5 & 6 & 2 & 2 \\
\hline \multirow[t]{2}{*}{ B } & Rheumatoid arthritis & 4 & 3 & 2 & 3 & 3 & 2 & & \\
\hline & Stroke & 2 & 1 & 2 & 2 & 1 & 1 & 1 & \\
\hline \multicolumn{2}{|l|}{ Total } & 6 & 4 & 4 & 5 & 4 & 3 & 1 & 0 \\
\hline \multirow[t]{4}{*}{$\mathrm{C}$} & Rheumatoid arthritis & 8 & 5 & 6 & 7 & 5 & 4 & 4 & 2 \\
\hline & Multiple sclerosis & 5 & 5 & 4 & 4 & 4 & 5 & 4 & 3 \\
\hline & Motor neurone disease & 1 & 1 & 1 & 1 & 1 & & & \\
\hline & Muscular dystrophy & 2 & & & 2 & 2 & 2 & & 1 \\
\hline \multicolumn{2}{|l|}{ Total } & 16 & 11 & 11 & 14 & 12 & 11 & 8 & 6 \\
\hline \multirow[t]{6}{*}{$\mathrm{D}$} & Rheumatoid arthritis & 3 & 2 & 2 & 3 & 3 & 3 & & 1 \\
\hline & Multiple sclerosis & 7 & 3 & 2 & 6 & 7 & 6 & 1 & 1 \\
\hline & Motor neurone disease & 3 & 1 & 1 & 2 & 3 & 2 & 1 & \\
\hline & Stroke & 2 & 2 & 2 & 1 & 2 & 1 & 1 & \\
\hline & Paraplegia & 1 & & & & & 2 & & 1 \\
\hline & Other & 2 & & & 2 & 2 & 2 & & \\
\hline \multicolumn{2}{|l|}{ Total } & 18 & 8 & 7 & 14 & 17 & 16 & 3 & 3 \\
\hline \multirow[t]{2}{*}{$\mathrm{E}$} & Rheumatoid arthritis & 1 & & & 1 & 1 & 1 & & \\
\hline & Multiple sclerosis & 2 & 1 & & 2 & 1 & 2 & & 1 \\
\hline \multicolumn{2}{|l|}{ Total } & 3 & 1 & & 3 & 2 & 3 & & 1 \\
\hline $\mathrm{F}$ & Multiple sclerosis & 2 & 2 & & 1 & 1 & 1 & & 0 \\
\hline \multicolumn{2}{|c|}{ All groups total } & 53 & 28 & 24 & 44 & 41 & 40 & 14 & 12 \\
\hline
\end{tabular}




\begin{tabular}{|c|c|c|c|c|}
\hline & \multicolumn{2}{|c|}{ Progressive disorders } & \multicolumn{2}{|c|}{ Non-progressive disorders } \\
\hline & $\begin{array}{c}\text { No of } \\
\text { subjects }\end{array}$ & $\begin{array}{l}\text { No }(\%) \text { with } \\
\text { umet needs }\end{array}$ & $\begin{array}{c}\text { No of } \\
\text { subjects }\end{array}$ & $\begin{array}{l}\text { No }(\%) \text { with } \\
\text { unmet needs }\end{array}$ \\
\hline \multicolumn{5}{|l|}{ Distribution in subgroups: } \\
\hline A & 3 & $3(100)$ & 9 & $5(55)$ \\
\hline B & 6 & $4(67)$ & 4 & $2.50)$ \\
\hline $\mathrm{C}$ & 34 & $16(47)$ & 12 & \\
\hline $\mathrm{D}$ & 22 & $13(59)$ & 29 & $5(17)$ \\
\hline $\mathrm{E}$ & 18 & $3(17)$ & 24 & \\
\hline $\mathrm{F}$ & 12 & $2(17)$ & 8 & \\
\hline Total & 95 & $41(43)$ & 86 & $12(14)$ \\
\hline \multicolumn{5}{|l|}{ Hospital attendances during previous 12 months: } \\
\hline Inpatients and outpatients & 15 & & 10 & $1(10)$ \\
\hline Outpatients only & 77 & $38(49)$ & 67 & $6(9)$ \\
\hline Total & 92 & $38(41)$ & 77 & $7(9)$ \\
\hline \multicolumn{5}{|l|}{ Contact with health professionals: } \\
\hline Sole regular contact with health professionals & 65 & $36(55)$ & 54 & $12(22)$ \\
\hline $\begin{array}{l}\text { Regular contact with health services and social } \\
\text { services }\end{array}$ & 30 & $5(17)$ & 32 & \\
\hline Total & 95 & $41(43)$ & 86 & $12(14)$ \\
\hline
\end{tabular}

\section{SERVICES AND BENEFITS}

Table VI summarises the number of subjects in each subgroup who were accepted for respite and day sitting services and who were found to be eligible for the mobility and attendance allowances before and after the interview. In groups $A$ to $D$, in sole regular contact with health professionals, the differences were most pronounced with increased uptake as follows: respite care $48 \%$ to $92 \%$, day care $55 \%$ to $89 \%$, mobility allowance $56 \%$ to $91 \%$, attendance allowance $55 \%$ to $93 \%$.

\section{Discussion}

Inadequacy of services for young physically disabled adults has been emphasised in several reports. ${ }^{9-12}$ This survey disclosed a considerable disparity in levels of unmet need in subjects whose sole regular contact was with health professionals (subgroups A to D) compared with those reassessed on a multidisciplinary basis by health and social services personnel. It also highlights that functional deterioration, particularly in

TABLE v-Communication disorders: speech therapy assessment

\begin{tabular}{|c|c|c|c|c|c|c|}
\hline \multirow[b]{2}{*}{ Group } & \multicolumn{2}{|c|}{ Grade 1 disability } & \multicolumn{2}{|c|}{ Grade 2 disability } & \multicolumn{2}{|c|}{ Grade 3 disability $\ddagger$} \\
\hline & $\begin{array}{l}\text { No of } \\
\text { subjects }\end{array}$ & $\begin{array}{l}\text { No ever } \\
\text { assessed by } \\
\text { speech } \\
\text { therapist }\end{array}$ & $\begin{array}{l}\text { No of } \\
\text { subjects }\end{array}$ & $\begin{array}{l}\text { No ever } \\
\text { assessed by } \\
\text { speech } \\
\text { therapist }\end{array}$ & $\underset{\text { subjects }}{\text { No of }}$ & $\begin{array}{l}\text { No ever } \\
\text { assessed by } \\
\text { speech } \\
\text { therapist }\end{array}$ \\
\hline A & 2 & 1 & 1 & & 6 & \\
\hline B & 3 & 1 & 7 & 1 & 9 & \\
\hline C & 5 & 2 & 6 & 2 & 3 & 2 \\
\hline D & 4 & 3 & 3 & 3 & 1 & 1 \\
\hline $\mathrm{E}$ & & & 5 & 1 & 2 & 1 \\
\hline Total & 14 & 7 & 22 & 7 & 21 & 4 \\
\hline
\end{tabular}

^Impossible for people who know him or her well to understand. tImpossible for strangers to understand. $\neq$ Difficult for strangers to understand. those with progressive disorders, may not be detected owing to inadequate or infrequent reassessments, or both.

Referral by health professionals entails assessing a patient's needs, monitoring changes in needs, and knowing the role of other agencies.9.12 However, significant unmet needs remained despite our study subjects consulting their general practitioners more frequently than subjects in other studies. ${ }^{12}$ Increased emphasis is required on the identity of and response to the changing needs of physically disabled people, as evidenced by failure of doctors to detect functional deterioration in general practice and hospital outpatient consultations. A hospital admission is frequently accompanied by a more in depth assessment, which may explain the better results for the 25 patients in this subcategory.

District nurses are considered to have an important role in the effective assessment and provision of community care. However, despite contact with patients between one and three times per week, the unmet needs in groups $C$ and $D$ suggest that certain community nurses either may not be carrying out the assessment tasks effectively or may not be reassessing clients adequately.

The comparison of results in groups $\mathrm{D}$ and $\mathrm{E}$ highlights the important assessment role of occupational therapists as cited by other workers. ${ }^{913-15}$ Those clients who received regular reviews fared better than those who were left to bear the responsibility of contacting the relevant services when the situation, in their opinion, so required. The lack of perception of both clients and carers on progressive deterioration of function and the lack of information of what services have to offer mean that the "on demand" service may not be enough. This study also reinforces the conclusions of other studies ${ }^{12}$ by highlighting deficits in the availability of valid, accurate, timely, and accessible information on both services and allowances for disabled people. The acquisition of independence from the carer in various activities of daily living was achieved in this study at relatively modest cost $-£ 3300$ (Somerset Social Services Department, personal communication).

Communication disorders are a source of considerable frustration and undoubtedly interfere with the quality of life. In addition, help is required for motor neurone disease patients with swallowing disorders." These results highlight deficits in the use of speech therapists in their assessment and treatment capacities. We acknowledge that stroke patients may be classified in the progressive or non-progressive disorder category. Their inclusion in the non-progressive category does not influence the main conclusion that deficits are highest in monitoring patients with progressive disorders. We also acknowledge that the Office of Population Censuses and Surveys categories of disability severity have not been fully validated, ${ }^{4}$ but this scoring system was used to illustrate the broad similarity of severity in clients from each of the six subgroups (table I).

The important role of voluntary services, both in the

TABLE VI-Provision of respite care, services, and allowances before and after assessment

\begin{tabular}{|c|c|c|c|c|c|c|c|c|c|}
\hline \multirow[b]{2}{*}{ Group } & \multirow[b]{2}{*}{$\begin{array}{l}\text { No of } \\
\text { subjects }\end{array}$} & \multicolumn{2}{|c|}{ No receiving respite care } & \multicolumn{2}{|c|}{$\begin{array}{l}\text { No receiving day care/day } \\
\text { sitting service }\end{array}$} & \multicolumn{2}{|c|}{ No receiving mobility allowance } & \multicolumn{2}{|c|}{$\begin{array}{c}\text { No receiving attendance } \\
\text { allowance }\end{array}$} \\
\hline & & $\begin{array}{c}\text { Before } \\
\text { assessment }\end{array}$ & $\begin{array}{c}\text { After } \\
\text { assessment }\end{array}$ & $\begin{array}{l}\text { Before } \\
\text { assessment }\end{array}$ & $\begin{array}{c}\text { After } \\
\text { assessment }\end{array}$ & $\begin{array}{l}\text { Before } \\
\text { assessment }\end{array}$ & $\begin{array}{c}\text { After } \\
\text { assessment }\end{array}$ & $\begin{array}{c}\text { Before } \\
\text { assessment }\end{array}$ & $\begin{array}{c}\text { After } \\
\text { assessment }\end{array}$ \\
\hline A & 12 & 3 & 9 & 2 & 9 & 5 & 11 & 6 & 11 \\
\hline B & 10 & 3 & 10 & 5 & 9 & 5 & 10 & 5 & 10 \\
\hline C & 46 & 20 & 42 & 23 & 40 & 27 & 42 & 26 & 42 \\
\hline $\mathrm{D}$ & 51 & 31 & 48 & 36 & 48 & 30 & 45 & 29 & 48 \\
\hline E & 42 & 42 & 42 & 39 & 40 & 42 & 42 & 42 & 42 \\
\hline $\mathrm{F}$ & 20 & 20 & 20 & 20 & 20 & 20 & 20 & 20 & 20 \\
\hline Total & 181 & $119(66 \%)$ & $171(94 \%)$ & $125(69 \%)$ & $166(92 \%)$ & $129(71 \%)$ & $170(94 \%)$ & $128(71 \%)$ & $173(96 \%)$ \\
\hline
\end{tabular}


provision of information and in providing support, has often been underestimated. This survey shows that, when available, their support is usually welcomed by both clients and carers and unmet needs are less.

In conclusion, deficiencies have been found in monitoring adults with severe physical disability whose sole regular contacts are health professionals. District health authorities and family health services authorities will need to consider how best to improve the assessment of needs of patients as they plan to implement care in the community.

1 Secretaries of State for Health. Caring for people. London: HMSO, 1989 2 Secretaries of State for Health. NHS and community care act. London: HMSO, 1990.

3 Cantrell E, Dawson J, Glastonbury G. Prisoners of handicap. London: RADAR, 1985.

4 Martin J, Meltzer $\mathrm{H}$, Elliot $\mathrm{D}$. The prevalence of disability among adults. OPCS surveys of disability in Great Britain. Report 1. London: HMSO, 1988. 5 Culyer AJ. Need and the National Health Service. London: Martin Robertson, 1976.
6 Williams A. Need-an economic exegesis. In: Culyer AJ, Wright KG, eds. Economic aspects of the health service. London: Martin Robertson, 1978.

Buchan H, Gray JAM, Hill A, Coulter A. Needs assessment made simple. Health Services foumal 1990;100:240-1.

8 Bradshaw J. A taxonomy of social need. In: McLachlan G, ed. Problems and progress in medical care: essays on current research. London: Oxford University Press, 1972.

9 Edwards FC, Warren MD. Health services for adults with physical disabilities. London: Royal College of Physicians, 1990.

10 Beardshaw V. Last on the list. London: King's Fund, 1988. (Research report 3.)

11 Patrick DL, Peach H, Gregg I. Disablement and care: a comparison of patient views and general practitioner knowledge. I R Coll Gen Pract 1982;32: 429-34.

12 Thomas A, Bax M, Coombs K, Goldson E, Smyth D, Whitmore K. The health and social needs of physically handicapped young adults: are they being me by the statutory services? Dev Med Child Neurol 1985;4(suppl):50.

13 Blaxter M. Principles and practice in rehabilitation. In: Report of the royal commission on the National Health Service. London: HMSO, 1979. (Cmnd 7615.)

14 Brechin A, Liddiard P. Look at it this way: new perspectives in rehabilitation. London: Hodder and Stoughton in association with Open University Press, 1981.

15 Robinson T. In worlds apart. London: Bedford Square Press, 1978

6 Campbell MJ, Enderby P. The management of motor neurone disease. f Neurol Sci 1984;64:65-71.

(Accepted 30 October 1992)

\title{
Long term follow up of severely ill patients who underwent urgent cardiac transplantation
}

\author{
D Mulcahy, M Fitzgerald, C Wright, J Sparrow, J Pepper, M Yacoub, K M Fox
}

\section{Abstract}

Objective-To assess long term survival $(>5$ years) and quality of life in severely ill patients referred for urgent cardiac transplantation.

Setting-Tertiary referral centres: before transplantation at the National Heart Hospital (late 1984 to end 1986); after transplantation at Harefield Hospital.

Subjects-Eighteen patients $(15$ men; three women) who had required intensive support in hospital before cardiac transplantation and were alive at short term follow up.

Interventions-Intravenous infusions of cardiac drugs (mean 2.2 infusions), intravenous diuretics (17 patients), and many other drugs before transplantation. Intra-aortic balloon counterpulsation (four patients), temporary pacing (two), and rescusitation from cardiac arrest (three). Patients had specialised nursing care on a medical intensive care unit in almost every case.

Main outcome measures-Long term survival in patients after urgent cardiac transplantation and perceived quality of life.

Results-Of 18 patients who were alive at short term follow up (mean (range) 19.4 (10-33) months), 14 were still alive in 1992 (69 (61-83) months). Ten still worked full time, and 11 reported no restrictions in their daily activities. Three of four patients who died in the intervening period survived $>5$ years after transplantation. Overall, 17 of 18 patients survived at least 5 years.

Conclusions-In severely ill patients who undergo urgent cardiac transplantation and survive in the short term, long term (5-7 year) survival and quality of life seem good.

\section{Introduction}

Cardiac transplantation has now become an accepted therapeutic option for many patients with terminal cardiac failure. A total of 3054 heart transplantations were reported to the registry of the International Society of Heart and Lung Transplantation in 1990, and overall actuarial survival rates at 1 and 5 years have been reported at $90 \%$ and $68 \%$ respectively. Of more than 16000 heart transplantations performed since the first human to human operation in 1967, over 1700 patients survived more than 5 years after surgery. ${ }^{\prime}$ The success of this fairly new treatment has led to increasing numbers of terminally ill patients being referred for consideration of transplantation, many of these being referred as a final option, when intensive support in hospital is required and when secondary end organ damage has often developed. Organ donation has not kept pace with the demands for transplantation, ${ }^{2}$ and a considerable minority of patients die having been accepted for, and while waiting for, transplantation. With the chronic shortage of donor organs a dilemma faces the physician who is referred a patient with terminal heart failure with or without secondary end organ damage who requires intensive support in hospital. Should treatment be withheld and the available donor organs donated to "more suitable" patients or should such ill patients be actively treated while waiting for a suitable donor organ, thus leading to a potential increase in the number of stable patients likely to deteriorate while awaiting "elective" transplantation?

In early 1988 we reported in this journal the short term outcome in 33 patients referred to the National Heart Hospital between late 1984 and the end of 1986 and who were accepted for urgent cardiac transplantation. ${ }^{3}$ All required intensive treatment in hospital with intravenous infusions of cardiac drugs, in addition to various combinations of intra-aortic balloon counterpulsation, peritoneal dialysis, ventilation, and temporary pacing to sustain life, and none had any prospect of discharge from hospital without a transplant. The seven patients who did not receive a transplant died in hospital, but 18 of 20 patients who survived to hospital discharge after transplantation were alive at short term follow up (mean (range) $19 \cdot 4$ (10-33) months). In this report we assess the long term (5-7 year) survival, exercise capacity, perceived quality of life, and employment in these 18 patients.

\section{Patients and methods}

Follow up data for the 18 patients who were alive when the 1988 report was assembled have been

Dr Mulcahy. 